\title{
Synthesis of aromatic lactone analogues of Lipoxin A4
}

\author{
Aya Ismael ${ }^{\dagger}$, Muhammad Zeeshan ${ }^{\dagger}$ and Jørn H. Hansen ${ }^{*}$ (0)
}

\begin{abstract}
Objective: Synthesis of novel aromatic Lipoxin A4 lactone analogues.

Results: Novel para-substituted aromatic lactone analogues of Lipoxin A4 have been synthesized in a convergent manner with six steps in the longest linear sequence in 12-13\% yields, employing 2-deoxy-D-ribose as a chiral pool starting material and the classical E-selective Wittig olefination.
\end{abstract}

Keywords: Lipoxin analogues, Aromatics, Wittig olefination, Lactones

\section{Introduction}

Lipoxins (LXs) are naturally occurring oxygenated derivatives of arachidonic acid that are produced and act at sites of inflammation [1-6]. Lipoxin A4 (LXA4) and Lipoxin B4 (LXB4) were first reported by Serhan and Samuelsson in 1984 [7]. They are biosynthesized from arachidonic acid via lipoxygenases and both LXA4 and LXB4 are known to exhibit potent and selective antiinflammatory activity. Even though LXs play a vital role in the resolution of inflammation, their use in therapeutics is compromised because of their rapid metabolism [8-11]. This instability dramatically reduces the potential of LXs to be used as pharmacological agents, thus providing the impetus for us and others to develop syntheses of more stable analogues.

In recent decades, significant progress has been made in the synthesis of lipoxin-analogues. In the first reported synthesis by Petasis et al., the triene core of LXA4 was replaced by a more stable benzene ring, which introduced metabolic stability while conserving crucial biological activity [12, 13]. A stereoselective synthesis of aromatic LXA4 and LXB4 was reported by O'Sullivan

\footnotetext{
*Correspondence: jorn.h.hansen@uit.no

${ }^{\dagger}$ Aya Ismael and Muhammad Zeeshan contributed equally to the manuscript and are presented in alphabetical order

Department of Chemistry, Chemical Synthesis and Analysis Division, UiT

The Arctic University of Norway, 9037 Tromsø, Norway
}

et al. where they utilized a series of advanced reactions (Sharpless epoxidation, Pd-mediated Heck coupling and diastereoselective reductions) to achieve the desired stereochemistry. The resulting analogs exhibited increased phagocytotic activity compared to the native LXA4 [6]. A number of other synthetic strategies have also been reported [14-21]. In this paper, we describe a different and potentially more flexible approach to the synthesis of aromatic lipoxin analogues in their lactone forms using simple and available starting materials and the classical Wittig olefination to craft the central double bond. This research note reports on the performance of our synthetic approach to two novel lipoxin A4 analogues.

\section{Main text}

\section{Results and discussion}

We envisioned a synthetic strategy as outlined in Fig. 1A in which the aliphatic side chain would be connected via Friedel-Craft acylation and phenolate alkylation to generate the ketone and ether analogues $\mathbf{1}$ and $\mathbf{2}$, respectively. The chiral diol moiety can be harvested from the chiral pool via an enantiomerically pure, commercially available 2-deoxy-D-ribose. The central double bond could be crafted via an $E$-selective Wittig-olefination.

The chiral pool fragment is introduced from aldehyde 7 (Fig. 1B), set up for the key Wittig olefination, which was synthesized starting from commercial 2-deoxy-D-ribose 

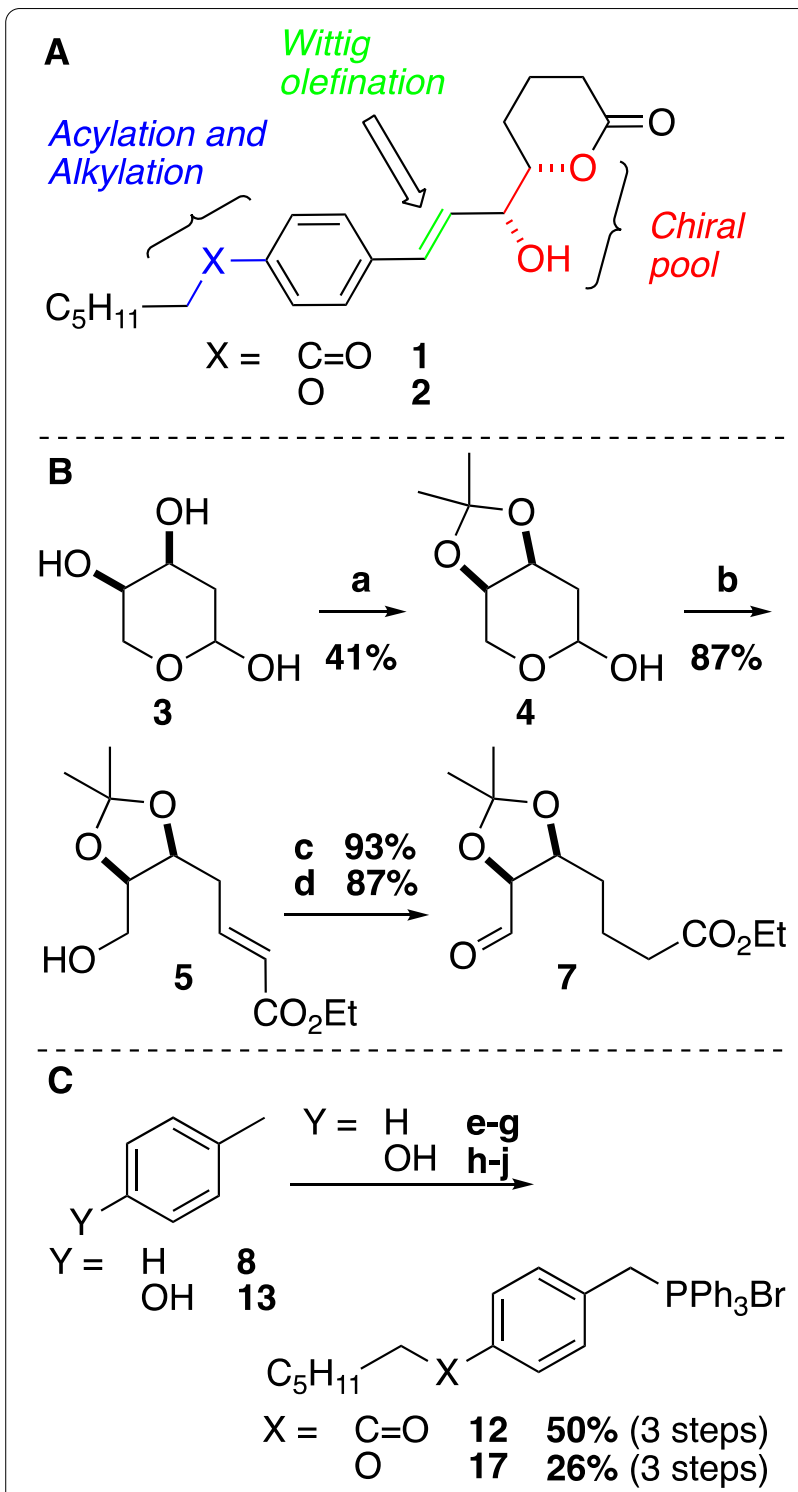

Fig. 1 A Key synthetic strategies towards the target lactones. B Synthesis of key intermediate 7; a) 2,2-dimethoxypropane, DMF, MS $5 \AA$, $0{ }^{\circ} \mathrm{C}, 3 \mathrm{~h}$, then rt overnight, 41\%; b) $\mathrm{Ph}_{3} \mathrm{PCHCO}_{2}$ Et, benzoic acid, toluene, reflux, 87\%; c) $\mathrm{H}_{2}$ (1 atm), Pd/C, EtOAc, rt, 93\%; d) SO $-\mathrm{Pyr}$, $\mathrm{Et}_{3} \mathrm{~N} / \mathrm{DMSO}, \mathrm{DCM}, \mathrm{rt}, 87 \%$. C Synthesis of key phosphonium salts 12 and 17; e) Heptanoyl chloride, $\mathrm{AlCl}_{3}, \mathrm{DCM}, 0{ }^{\circ} \mathrm{C}$, r.t, 30 min -1 h, 73\%; f) NBS, THF, $\mathrm{H}_{2} \mathrm{O}$, hv, r.t, 83\%; g) $\mathrm{PPh}_{3}$, acetone, reflux, 3 h, 82\%. h) Heptyl bromide, $\mathrm{K}_{2} \mathrm{CO}_{3}, \mathrm{CH}_{3} \mathrm{CN}$, 24 h, reflux, $72 \%$, or; $\mathrm{KOH}, \mathrm{EtOH}, \mathrm{H}_{2} \mathrm{O}$, $24 \mathrm{~h}$, reflux, 76\%; i) NBS, $\mathrm{Bz}_{2} \mathrm{O}_{2}, \mathrm{DCM}$, reflux, 9 h, 48\%. j) $\left.=\mathrm{g}\right), 72 \%$

(3). In a four-step procedure, protecting the diol moiety as a cyclic acetal via acid-catalysis, followed by a tandem ring-opening/Wittig olefination, Pd-catalyzed hydrogenation of the $\alpha, \beta$-unsaturated double bond and a ParikhDoering oxidation of the resulting alcohol, the aldehyde 7 was formed in overall $29 \%$ yield from 3 . The appropriate phosphonium salts for the key Wittig olefination (12 and
17) were generated from toluene (8) and $p$-cresol (13), respectively (Fig. 1C). 8 was subjected to Friedel-Craft acylation with heptanoyl chloride, followed by lightinduced benzylic radical bromination and subsequent nucleophilic displacement with triphenylphosphine to generate ketone $\mathbf{1 2}$ in $50 \%$ yield over 3 steps. 13 was treated with hexyl bromide and base, followed by benzylic bromination with $N$-bromosuccinimide (NBS) and the final nucleophilic displacement with triphenylphosphine to form phosphonium salt 17 in overall 26\% over 3 steps. The typical Wohl-Ziegler benzylic mono-bromination could not be achieved in the system with the electron-donating alkoxy-group. An acceptable conversion to the benzylic bromide was achieved with NBS and a catalytic amount of dibenzoyl peroxide in the presence of dichloromethane ( $48 \%$ yield). A number of reported conditions for phosphonium salt formation initially failed for the formation of $\mathbf{1 7}$ but, it was found that a relatively short reaction time ( $3 \mathrm{~h}$ in refluxing acetone) was crucial to achieve $72 \%$ yield in this step.

The phosphonium salts 12 and 17 were treated with base and the resulting ylenes coupled with aldehyde 7 in Wittig olefinations to yield the desired products 18 and 19 in $60 \%$ and $61 \%$ yields respectively (Fig. 2). We were unable to extract the $E / Z$-ratios from the Wittig olefination steps from the raw data but minor peaks appear in spectra of purified materials. The final removal of the acetal group from both $\mathbf{1 8}$ and $\mathbf{1 9}$ under acidic conditions gave $70 \%$ and $75 \%$ yields of the target lactones $\mathbf{1}$ and 2 , respectively. The unprotected diol esters were not detected directly but are likely intermediates in the formation of the lactones via spontaneous cyclization.

In summary, we have successfully synthesized two novel trans-substituted aromatic lactone analogues of Lipoxin A4 in a convergent manner with six steps in the longest linear sequence using simple transformations and affordable reagents in overall $12-13 \%$ yield.

\section{Methods}

All reagents and solvents were purchased from commercial sources. The progress of the reactions were monitored by thin-layer chromatography (TLC) using Merck pre-coated silica gel plates $\left(60 \mathrm{~F}_{254}\right)$. The TLC plates were visualized using either ultraviolet light or by immersion in a solution of phosphomolybdic acid, followed by heating. For preparative purification, flash column chromatography was carried out using silica gel from Merck (Silica gel 60, 0.040-0.063 mm). The intermediates and products were characterized by NMR on a $400 \mathrm{MHz}$ Bruker Avance III HD. Chemical shifts $(\delta)$ are reported in ppm relative to the residual solvent peak $\left(\mathrm{CDCl}_{3}: \delta_{\mathrm{H}} 7.26\right.$ and $\delta_{\mathrm{C}} 77.16$; methanol- $\mathrm{d}_{4}: \delta_{\mathrm{H}} 3.31$ and $\delta_{\mathrm{C}} 49.00$, deuterium oxide: $\delta_{\mathrm{H}} 4.79$ and $\delta_{\mathrm{C}} 49.00 ; \mathrm{DMSO}-d_{6} \delta_{\mathrm{H}} 2.51$ and 


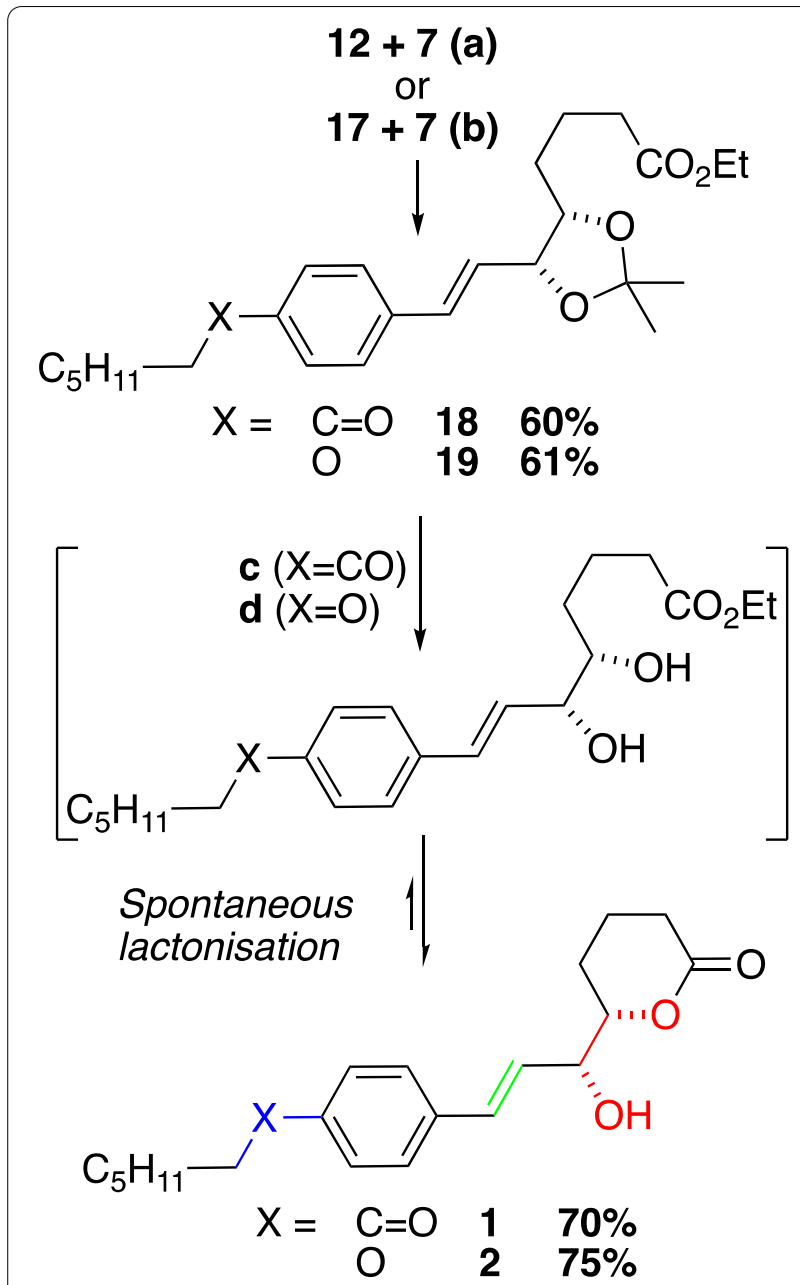

Fig. 2 a $\mathrm{K}_{2} \mathrm{CO}_{3}, \mathrm{THF}, 0^{\circ} \mathrm{C}, 1 \mathrm{~h}$ - r.t. , $60 \%$; $\mathbf{b} \mathrm{K}_{2} \mathrm{CO}_{3}, \mathrm{THF}, 0^{\circ} \mathrm{C}$, $1 \mathrm{~h}$ - r.t, $61 \%$; c $1 \mathrm{~N} \mathrm{HCl}, \mathrm{THF}, 0^{\circ} \mathrm{C}$ - r.t. , $70 \%$. d $1 \mathrm{~N} \mathrm{HCl}, \mathrm{THF}, 0^{\circ} \mathrm{C}$ - r.t., $75 \%$

$\left.\delta_{\mathrm{C}} 39.52\right)$. The raw data was analysed with MestReNova (Version 10.0.2-15,465). High-resolution mass spectra were obtained on a Thermo electron LTQ Orbitrap XL spectrometer, which was operated in electrospray ionization mass spectrometry (ESI) mode. The data was analyzed with Thermo Scientific Xcalibur software. Infrared spectra were recorded on a Varian 700e FT-IR spectrometer and bands are reported in wavenumbers $\left(\mathrm{cm}^{-1}\right)$.

Detailed synthetic procedures and analytical data can be found in Additional file 1.

\section{Limitations}

The initial protection of the chiral pool sugar $\mathbf{3}$ is difficult to achieve in high yields and is a weak point in this synthetic strategy. Moreover, the benzylic radical bromination of electron-rich aromatics is a clear limitation of the synthesis of the phosphonium salts. Alternative strategies for this could be considered, e.g. direct chloromethylation. A third limitation appears to be that isomers generated in the key Wittig olefination step are difficult to separate.

\section{Abbreviations}

LXs: Lipoxins; LXA4: Lipoxin A4; LXB4: Lipoxin B4; DMF: Dimethyl formamide; MS: Molecular sieves; rt: Room temperature; DMSO: Dimethyl sulfoxide; DCM: Dichloromethane; NBS: N-Bromosuccinimide; THF: Tetrahydrofuran; Bz: Benzoyl; TLC: Thin-Layer Chromatography; NMR: Nuclear Magnetic Resonance; FT-IR: Fourier Transform-Infrared Spectroscopy.

\section{Supplementary Information}

The online version contains supplementary material available at https://doi. org/10.1186/s13104-022-05917-4.

Additional file 1. Experimental procedures, equipment, spectroscopic and analytical data for compounds presented in the manuscript.

\section{Acknowledgements}

The authors acknowledge preliminary investigations in the project conducted by Mr. Keven Mardy, Ms. Laura Krieger and Ms. Lina Malinauskaité. Assistance with NMR and mass spectrometry measurements was provided by Mr. Jostein Johansen and Dr. Truls Ingebrigtsen.

\section{Authors' contributions}

$\mathrm{Al}$ and $\mathrm{MZ}$ contributed equally to this manuscript. Al and $\mathrm{MZ}$ conducted experiments, analyzed data and contributed to manuscript. JHH designed research, supervised experiments, analyzed data and contributed to manuscript. All authors read and approved the final manuscript.

\section{Funding}

Open Access funding provided by UiT The Arctic University of Norway. The authors would like to acknowledge financial support for this project from the Department of Chemistry at UiT The Arctic University of Norway and the Olav Thon Foundation. The publication charges for this article have been funded by a Grant from the publication fund of UiT The Arctic University of Norway.

\section{Availability of data and materials}

Spectroscopic data for all intermediates and final products can be found in a separate additional file and is also available from the corresponding author upon request.

\section{Declarations}

Ethics approval and consent to participate Not applicable.

\section{Consent for publication}

Not applicable.

\section{Competing interests}

The authors declare that they have no competing interests.

Received: 29 September 2021 Accepted: 25 January 2022 Published online: 09 February 2022

\section{References}

1. Silva M, Correia-Neves M. Neutrophils and macrophages: the main partners of phagocyte cell systems. Front Immunol. 2012. https://doi.org/10. 3389/fimmu.2012.00174.

2. Duffy CD, Guiry PJ. Recent advances in the chemistry and biology of stable synthetic Lipoxin analogues. MedChemComm. 2010;1:249-65. 
3. van Lent PL, Licht R, Dijkman H, Holthuysen $A E$, Berden JH, van den Berg WB. Uptake of apoptotic leukocytes by synovial lining macrophages inhibits immune complex-mediated arthritis. J Leukoc Biol. 2001;70:708-14.

4. Vandivier RW, Fadok VA, Ogden CA, Hoffmann PR, Brain JD, Accurso FJ, Fisher JH, Greene KE, Henson PM. Impaired clearance of apoptotic cells from cystic fibrosis airways. Chest. 2002;121:89s.

5. Gaipl US, Kuhn A, Sheriff A, Munoz LE, Franz S, Voll RE, Kalden JR, Herrmann M. Clearance of apoptotic cells in human SLE. Curr Dir Autoimmun. 2006;9:173-87.

6. O'Sullivan TP, Vallin KS, Shah ST, Fakhry J, Maderna P, Scannell M, Sampaio AL, Perretti M, Godson C, Guiry PJ. Aromatic lipoxin A4 and lipoxin B4 analogues display potent biological activities. J Med Chem. 2007;50:5894-902.

7. Serhan CN, Hamberg M, Samuelsson B. Lipoxins: novel series of biologically active compounds formed from arachidonic acid in human leukocytes. Proc Natl Acad Sci USA. 1984;81:5335-9.

8. McMahon B, Godson C. Lipoxins: endogenous regulators of inflammation. Am J Physiol Renal Physiol. 2004;286:F189-201.

9. Brink C, Dahlén S-E, Drazen J, Evans JF, Hay DWP, Nicosia S, Serhan CN, Shimizu T, Yokomizo T. International Union of Pharmacology XXXVII. Nomenclature for Leukotriene and Lipoxin Receptors. Pharmacol Rev. 2003;55:195.

10. Ye RD, Boulay F, Wang JM, Dahlgren C, Gerard C, Parmentier M, Serhan $\mathrm{CN}$, Murphy PM. International Union of Basic and Clinical Pharmacology LXXIII Nomenclature for the Formyl Peptide Receptor (FPR) Family. Pharmacol Rev. 2009;61:119.

11. Chiang N, Serhan CN, Dahlén S-E, Drazen JM, Hay DWP, Rovati GE, Shimizu T, Yokomizo T, Brink C. The Lipoxin receptor ALX: Potent ligandspecific and stereoselective actions in vivo. Pharmacol Rev. 2006;58:463.

12. Petasis NA, Akritopoulou-Zanze I, Fokin W, Bernasconi G, Keledjian R, Yang R, Uddin J, Nagulapalli KC, Serhan CN. Design, synthesis and bioactions of novel stable mimetics of lipoxins and aspirin-triggered lipoxins. Prostaglandins Leukot Essent Fatty Acids. 2005;73:301-21.

13. Petasis N, Keledjian R, Sun Y-P, Nagulapalli KC, Tjonahen E, Yang R, Serhan $\mathrm{CN}$. Design and synthesis of benzo-lipoxin A4 analogs with enhanced stability and potent anti-inflammatory properties. Bioorg Med Chem Lett. 2008;18:1382-7.

14. Phillips ED, Chang H-F, Holmquist CR, McCauley JP. Synthesis of methyl (5S,6R,7E,9E,11Z,13E, 15S)-16-(4-fluorophenoxy)-5,6,15-trihydroxy-7,9,11,13-hexadecatetraenoate, an analogue of 15R-lipoxin A4. Bioorg Med Chem Lett. 2003;13:3223-6.

15. Yadav JS, Barma DK, Dutta D. Stereoselective Total Synthesis of 5(S), 6(R), 15(S)-Trihydroxy-7(E), 9(E), 11 (Z),13(E)-Eicosatetraenoic Acid (Lipoxin A). Tetrahedron Lett. 1998;39:143-6.

16. Rodríguez AR, Spur BW. Total synthesis of aspirin-triggered 15-epi-lipoxin A4. Tetrahedron Lett. 2001; 42: 6057-60.

17. Nicolaou KC, Marron BE, Veale CA, Webber S, Serhan CN. Total synthesis of novel geometric isomers of lipoxin A4 and lipoxin B4. J Org Chem. 1989;54:5527-35.

18. Nicolao KC, Veale CA, Webber SE, Katerinopoulos H. Stereocontrolled total synthesis of lipoxins A. J Am Chem Soc. 1985;107:7515-8.

19. Duffy CD, Maderna P, McCarthy C, Loscher CE, Godson C, Guiry PJ. Synthesis and biological evaluation of pyridine-containing Lipoxin A4 analogues. ChemMedChem. 2010;5:517-22.

20. O'Sullivan TP, Vallin KSA, Ali Shah ST, Fakhry J, Maderna P, Scannell M, Sampaio ALF, Perretti M, Godson C, Guiry PJ. Aromatic Lipoxin A4 and Lipoxin B4 analogues display potent biological activities. J Med Chem. 2007;50:5894-902.

21. Haberlin GG, McCarth C, Doran R, Loscher CE, Guiry PJ. Asymmetric synthesis and biological evaluation of 1,3- and 1,4-disubstituted benzo-type lipoxin A4 analogues. Tetrahedron. 2014;70:6859-69.

\section{Publisher's Note}

Springer Nature remains neutral with regard to jurisdictional claims in published maps and institutional affiliations.

Ready to submit your research? Choose BMC and benefit from:

- fast, convenient online submission

- thorough peer review by experienced researchers in your field

- rapid publication on acceptance

- support for research data, including large and complex data types

- gold Open Access which fosters wider collaboration and increased citations

- maximum visibility for your research: over 100M website views per year

At BMC, research is always in progress.

Learn more biomedcentral.com/submissions 